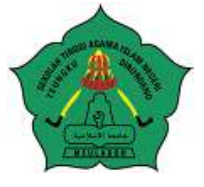

AT-TASYRI' Jurnal Ilmiah Prodi Muamalah

P-ISSN: 2085-2541, E-ISSN: 2715-7865

Volume 12, Nomor 1, Juni 2020

https://ejournal.staindirundeng.ac.id/index.php/Tasyri

\title{
STRATEGI MANAJEMEN SUMBER DAYA INSANI \\ PADA PROSES KONVERSI BPR MUSTAQIM ACEH \\ (Analisis Realitas dan Idealitas Kualifikasi Sumber Daya Insani \\ Berdasarkan Nilai-Nilai Islam)
}

\author{
Raudhatun Nafisah, M.Ag. \\ Program Studi Magister Ilmu Agama Islam \\ Pascasarjana UIN Ar-Raniry Banda Aceh \\ raudhatun92@gmail.com
}

\begin{abstract}
Abstrak
Proses konversi yang dilalui oleh BPR Mustaqim membutuhkan kesiapan Sumber Daya Insani (SDI) untuk keberhasilan perubahan status dari sistem konvensional ke sistem syariah. Problema yang dihadapi sekarang, SDI yang mempunyai kapabilitas dalam bidang ekonomi dan syariah, serta berkarakter Islami masih kurang memadai. Hal ini menjadi tujuan penelitian yaitu untuk menganalisis kualifikasi sumber daya insani yang ideal pada PD. BPR Mustaqim dalam proses konversi, kemudian untuk menganalisis strategi manajemen sumber daya insani sesuai dengan nilai-nilai Islam untuk diterapkan pada konversi PD BPR Mustaqim. Penelitian ini menggunakan pendekatan kualitatif dengan menggunakan metode deskriptif, yakni mengklasifikasi kemudian menguraikan kualifikasi SDI, baik kualifikasi yang telah ditentukan oleh BPR Mustaqim maupun kualifikasi ideal sesuai dengan nilai-nilai Islam yang dibutuhkan pada BPR Mustaqim untuk keberhasilan konversi ke syariah. Berdasarkan realitas pada BPR Mustaqim menunjukkan bahwa kualifikasi SDI dan strategi manajemen belum optimal dalam proses konversi. Pada aspek kualifikasi SDI, BPR Mustaqim harus mengoptimalkan pengetahuan SDI tentang perbankan syariah, serta meningkatkan religiusitas dengan cara mengadakan kegiatan keagamaan. Sementara dari strategi manajemen SDI, seharusnya BPR Mustaqim melakukan proses rekrutmen, seleksi, pelatihan dan pengembangan, kompensasi, penilaian kinerja dan hubungan antarkaryawan sesuai dengan tujuan konversi, yakni prosedur penerapannya disesuaikan dengan nilai-nilai Islam.
\end{abstract}

Kata Kumci: Strategi, Manajemen SDI, Proses Konversi

\begin{abstract}
BPR Mustaqim Bank needs to prepare its human resources (HR) to be success in the conversion process from conventional to sharia system. However, the major problem is that it lacks of qualified HR who is competent (have capabilities in the field of economy and sharia), and has Islamic characters. The objective of this study was then to elaborate the concept of human resources management with Islamic values to achieve qualification and strategy of human resource management during the conversion process of BPR Mustaqim Bank. This study carried out qualitative approach by using descriptive method. It involved classifying and describing qualifications of the HR, both qualifications determined by the bank and ideal qualifications in line with Islamic values required by the bank for the successful conversion process to sharia system. Based on the reality, the HR qualification in BPR Mustaqim Bank are not fully ideal yet, either in terms of the HR qualification or the HR management strategy. In
\end{abstract}


the aspect of HR qualification, BPR Mustaqim Bank should optimize the knowledge of the HR on sharia banking, and improve their religiosity by conducting religious activities. Meanwhile, to improve HR management strategy, BPR Mustaqim Bank should perform recruitment, selection, training and development process, compensation, and employee performance appraisal and relationship in line with the conversion purposes, in which the application procedure is adjusted to Islamic values.

\section{Keywords: Strategy, Human Resources Management, Conversion Process}

\section{A. PENDAHULUAN}

Pertumbuhan perbankan syariah di Indonesia didorong oleh beberapa aspek, diantaranya ekspansi jaringan kantor ke berbagai wilayah, meningkatnya program sosialisasi dan edukasi kepada masyakakat, peningkatan kualitas layanan bank syariah, dan pengesahan Undang-undang pendukung operasional bank syariah ${ }^{1}$ Menurut data terakhir Otoritas Jasa Keuangan edisi Februari 2017, memperlihatkan bahwa jumlah jaringan kantor perbankan syariah

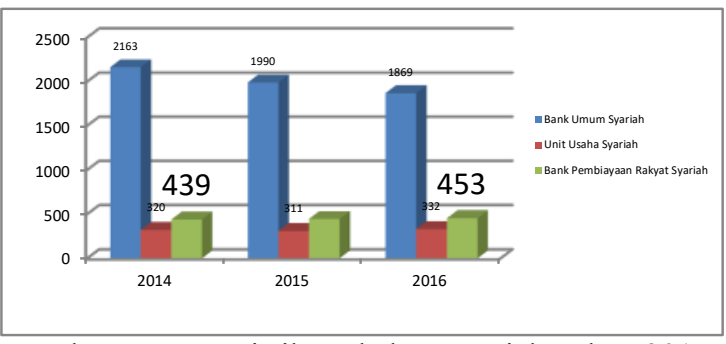

Sumber: Data Statistik Perbakan Syariah Tahun 2017

\section{Gambar 1. Pertumbuhan Jaringan Kantor} Perbankan Syariah

Berdasarkan pertumbuhan di atas, dapat kita lihat bahwa jaringan kantor perbankan syariah dari 2014 sampai 2016 mengalami penurunan, tetapi jika dilihat dari sisi aset bank syariah mengalami peningkatan signifikan yaitu pada tahun 2014 sebesar Rp. 272.344 Miliar, tahun 2015 sebesar Rp. 296.262 dan 2016 sebesar Rp. 356.504 Miliar.
Salah satu penyebab peningkatan aset pada tahun 2016 sebesar 5,46\% ialah perubahan status PT. Bank Aceh, di mana kontribusinya atas aset bank syariah adalah $5,13 \%$. ${ }^{2}$ Perubahan status ini disebut dengan istilah konversi yakni perubahan seluruh sistem konvensional menjadi sistem syariah yang didasarkan pada Peraturan Bank Indonesia (PBI) Nomor 11/15/PBI/2009 dan Peraturan Otoritas Jasa Keuangan No. 64/POJK.03/2016. Peraturan tersebut tidak hanya mengatur proses konversi menjadi Bank Umum Syariah, tetapi juga berlaku bagi Bank Perkreditan Rakyat yang ingin berubah menjadi Bank Pembiayaan Rakyat Syariah. Secara umum, persyaratan yang harus dipenuhi oleh setiap bank untuk konversi ialah: ${ }^{3}$

1. Menyesuaikan anggaran dasar;

2. Memenuhi persyaratan permodalan;

3. Menyesuaikan persyaratan Direksi dan Dewan Komisaris;

4. Membentuk DPS

5. Menyesuaikan laporan Keuangan sebagai bank syariah.

Persyaratan di atas merupakan syarat umum yang harus dipenuhi oleh setiap perbankan konvensional untuk konversi ke sistem syariah, tidak terkecuali Bank Perkreditan Rakyat. Adapun syarat krusial

\footnotetext{
${ }^{1}$ Halim Alamsyah, Perkembangan dan Prospek Perbankan Syariah Indonesia Tantangan Dalam Menyongsong MEA 2105, disampaikan dalam Ceramah Ilmiah Ikatan Ahli Ekonomi Islam (IAEI), Milad ke-8 IAEI, 13 April 2012, http://www.bi.go.id, diakses 25 April 2017.

${ }^{2}$ Republika, BPD Dorong Lakukan Konversi, republika.co.id, diakses 27 April 2017.

${ }^{3}$ Peraturan Otoritas Jasa Keuangan 64/POJK.03/2016 tentang Perubahan Kegiatan Usaha Bank Konvensional menjadi Bank Syariah.
} 
lainnya ialah keahlian sumber daya insani (SDI) di bidang perbankan syariah. Syarat ini diatur dalam Undang-undang No. 21 tahun 2008 terkait perizinan bank beroperasi dengan sistem syariah. ${ }^{4}$

Salah satu perbankan yang membutuhkan kesiapan SDI untuk proses konversi ialah BPR Mustaqim Sukamakmur. Bank ini merupakan lembaga milik daerah yang berorientasi pada segmen bisnis usaha mikro, kecil dan menengah (UMKM). Bank ini merupakan perusahaan milik daerah milik pemerintah Aceh yang didirikan pada tahun 1984. Saat ini jaringan kantor PD BPR Mustaqim telah tersebar diberbagai wilayah Aceh, seperti Banda Aceh, Aceh Besar, Aceh Jaya, Aceh Selatan, Aceh Barat, Aceh Tenggara dan wilayah lainnya. Adapun fokus utama dari PD BPR Mustaqim pada tahun 2017 ialah melakukan proses percepatan konversi, sehingga SDI menjadi faktor krusial yang menentukan berhasilnya konversi.

Secara kuantitas, karyawan BPR Mustaqim telah memenuhi kebutuhan operasional, tetapi dari segi kualitas karyawan belum seluruhnya memahami SOP yang disusun oleh pihak bank. ${ }^{5}$ Realitas ini tentunya membutuhkan kerja keras dari seluruh pihak, baik itu Komisaris, Dewan Direksi dan seluruh karyawan BPR Mustaqim. Oleh sebab itu, dibutuhkan Manajemen SDI yang handal untuk mendukung proses konversi. Adapun proses yang semestinya dilakukan oleh BPR Mustaqim ialah merekrut, mengembangkan, memotivasi serta mengevaluasi keseluruhan sumber daya manusia yang diperlukan perusahaan untuk mencapai tujuan konversi tersebut. ${ }^{6}$
Keseluruhan proses penyiapan SDI di atas, membutuhkan strategi khusus agar perencanaan konversi pada tahun 2017 dapat dilaksanakan. Strategi Manajemen Sumber Daya Insani (MSDI) diperlukan dalam rangka meningkatkan pemahaman karyawan BPR Mustaqim terkait konsep bank syariah baik secara teoritis maupun praktis. Berkaitan dengan ini, OJK belum menentukan kualifikasi SDI khusus yang dapat digunakan sebagai standar konversi MSDI. Dengan kata lain, kualifikasi SDI diserahkan sepenuhnya kepada kebijakan BPR Mustaqim, sehingga kompetensi karyawan sangat ditentukan oleh kebijakan tersebut. Hal ini tentunya menimbulkan permasalahan baru, jika kemampuan SDI setelah konversi tidak sesuai dengan kebutuhan bank syariah, sehingga diperlukan perumusan kualifikasi khusus yang sesuai dengan nilai-nilai Islam.

Penerapan nilai-nilai Islam dalam Manajemen Sumber Daya Islam merupakan manifestasi dari nilai-nilai yang terkandung dalam Al-Quran dan Hadis, seperti nilai tauhid, keadilan, transparansi, kejujuran, istiqamah, amanah, profesionalisme, tanggung jawab dan nilai Islam lainnya. Semua nilai tersebut terangkum dalam Manajemen Sumber Daya Insani. Problematika selanjutnya ialah belum ditemukan kualifikasi SDI yang ideal untuk diterapkan dalam proses konversi BPR Mustaqim. Kualifikasi yang dimaksud di sini ialah penentuan standar Sumber Daya Manusia yang sesuai dengan nilai-nilai Islam guna menyiapkan karyawan yang sesuai dengan kebutuhan bank syariah. Oleh sebab itu, diperlukan perumusan kualifikasi SDI ideal yang dapat diterapkan secara praktis

${ }^{4}$ Undang-undang No. 21 Tahun 2008 pasal 5 tentang Perizinan Bank Beroperasi Secara Syariah baik Bank Umum Syariah, Unit Usaha Syariah, dan Bank Pembiayaan Rakyat Syariah.

${ }^{5}$ Ibid

${ }^{6}$ Sadono Sukirno, Pengantar Bisnis, (Jakarta: Kencana, 2006), hal. 173. 
dalam strategi BPR Mustaqim untuk meningkatkan kualitas karyawannya.

Kualifikasi yang dibutuhkan BPR Mustaqim meliputi pemahaman perbankan syariah, keterampilan dalam memberikan perhitungan syariah, sikap dan moral yang Islami, serta religiusitas. Untuk menerapkan kualifikasi tersebut, pihak BPR Mustaqim harus melakukan strategi yang mampu memberdayakan karyawan lama dan meningkatkan kualitas karyawan yang baru.

Realitas yang terlihat pada BPR Mustaqim, strategi dalam praktek manajemen SDI yang ditempuh oleh BPR Mustaqim masih menggunakan teknik dan prosedur yang lama, seperti pada proses rekrutmen dan seleksi calon karyawan baru. Hal ini tentunya kurang sesuai dengan tujuan konversi yang diharapkan oleh BPR Mustaqim yakni menyiapkan SDI yang memahami sistem ekonomi Islam secara umum dan perbankan syariah secara khusus.

Perumusan MSDI di atas, didorong oleh problema perbankan syariah saat ini, sebagaimana disebutkan oleh Asnaini yaitu kendala dalam perbankan syariah adalah kurangnya sumber daya manusia yang mengerti manajemen perbankan syariah, untuk itu kerjasama dengan perguruan tinggi Islam yang memiliki jurusan perbankan syariah sudah seharusnya dilakukan, namun kenyataannya, banyak bank syariah yang memakai sumber daya manusia dengan dasar perbankan konvensional. ${ }^{7}$ Menurut Rozalinda menyatakan bahwa sumber daya manusia merupakan salah satu kunci penting untuk menjaga kualitas kinerja bank syariah, sehingga dibutuhkan usaha mengembangkan dan mendidik karyawan secara berkesinambungan. $^{8}$

Tri Wikaningrum menambahkan bahwa praktik manajemen sumber daya manusia bagi sebagian besar responden bank syariah kurang optimal. Hal ini termasuk alokasi waktu pelatihan dan frekuensi pelaksanaan, kejelasan dasar untuk pengaturan promosi, jenis dan jumlah kompensasi yang kurang kompetitif bila dibandingkan dengan jenis pekerjaan yang sama di bank lain, serta penilaian kinerja yang kurang berorientasi pada pengembangan karyawan. ${ }^{9}$ Selain itu, Fahadil menjelaskan dalam tulisannya mengenai suatu formulasi untuk meningkatkan sumber daya insani pada lembaga keuangan syariah, yaitu dengan (1) membangun manajemen sumber daya insani yang profesional, dan (2) mendirikan pusat pendidikan dan penelitian, serta sertifikasi profesi bagi calon pekerja dan pekerja lembaga keuangan syariah. ${ }^{10}$ Muhammad Mustaqim menyebutkan bahwa manajemen sumber daya manusia seharusnya dirumuskan prinsip amanah, prinsip kepemilikan terbatas, prinsip kerjasama dalam kebaikan, prinsip tanggung jawab sosial, prinsip kepemilikan bersama, prinsip distribusi ekonomi dan prinsip keadilan. ${ }^{11}$

\footnotetext{
${ }^{7}$ Asnaini, Pengembangan Mutu SDI Perbankan Syari'ah: Sebagai Upaya Pengembangan Ekonomi Islam, La_Riba,JurnalEkonomilslamVol.II,No.1, Juli2008, diakses 27 Februari 2015.

${ }^{8}$ Rozalinda, Konsep Manajemen Sumber Daya Manusia: Implementasi pada Industri Perbankan Syariah, Jurnal Al Masraf (Jurnal Lembaga Keuangan dan Perbankan)-Volume 1, No.1, Januari-Juni 2016, diakses 20 November 2016.

${ }^{9}$ Tri Wikaningrum, Praktek dan Kebijakan Manajemen Sumber Daya Manusia pada Perbankan Syariah, Jurnal Siasat Bisnis Vol. 15, No.1 Januari 2011, diakses 15 Desember 2016.

${ }^{10}$ Fahadil Amin Al Hasan dan Muhammad IrfanMaulana, Meningkatkan Kualitas Sumber Daya Insani Di Lembaga Kuangan Syariah Dalam Menghadapi Persaingan Global, SOSIO DIDAKTIKA: Social Science Education Journal, 3 (1), Juni2016, 27-36,diakses 27 Februari 2017.

${ }^{11}$ Muhammad Mustaqim, Prinsip Syariah dalam Manajemen Sumber Daya Manusia (Studi Implementasi Manajemen Sumber Daya Manusia UMKM di Kudus), Jurnal Penelitian Vol. 10, No. 2, Agustus 2016,
} 


\section{B. KAJIAN PUSTAKA}

Penelitian ini bedasarkan dugaan belum begitu maksimalnya sumberdaya insani yang terisi pada bank syariah. Saat ini hasil observasi penulis masih banyak karyawan pada bank syariah yang belum memahami betul liteterasi pada bank syariah baik, manajemen operasional, fungsi akad dan perbedaan bank syariah dengan bank konvensional.

Kemudian penelitian merupakan kajian yang menganalisis tinjauan nilai-nilai Islam terhadap penerapan strategi pada MSDI di PD. BPR Mustaqim. Adapun penelitian sejenis dengan penelitian ini, antara lain penelitian dari Tri Wikaningrum yang mengidentifikasi kebijakan dan praktek pengembangan Sumber Daya Insani (SDI) di bank syariah, kemudian menganalisis pengaruhnya terhadap kinerja organisasi. ${ }^{12}$ Selanjutnya kajian Rozalinda yang membahas tentang konsep manajemen SDM dengan penerapan pada perbankan syariah. ${ }^{13}$ Kemudian Fahadil meneliti tentang cara meningkatkan kualitas SDM di lembaga keuangan syariah dengan menggunakan dua metode, yaitu menbangun manajemen SDM profesional, mendirikan pusat pendidikan dan penelitian. $^{14}$

Asnaini memfokuskan kajiannya pada pengembangan mutu SDM perbankan syariah dengan meningkatkan Pelatihan SDM perbankan syariah untuk mewujudkan sistem perbankan syariah yang benar. ${ }^{15}$ Rita Monica, dalam penelitiannya menyimpulkan bahwa pelatihan yang diadakan selama ini kurang efektif serta tidak mempunyai pengaruh signifikan terhadap peningkatan kinerja pegawai pada bank BNI Bukittinggi. Sehingga dapat disimpulkan peningkatan kinerja pegawai dipengaruhi oleh faktor lainnya. ${ }^{16}$ Lain halnya dengan Puri Hariyadi Nugroho, dalam penelitiannya menyimpulkan bahwa bank syariah masih terus mengembangkan sistem manajemen SDM yang berlandaskan kompetensi. ${ }^{17}$

Ahmad Aulia, memfokuskan pada upaya yang dilakukan oleh bank Syariah Bukopin Cabang Melawai dalam meningkatkan etos kerja karyawannya yaitu memberikan pelatihan (Training) kepada seluruh pegawainya secara rutin, memberikan reward dan punishment, melakukan proses assessment untuk mengetahui potensi dan kompetensi karyawannya, serta memberikan pengembangan terhadap pegawai lama dengan sistem promosi dan mutasi. ${ }^{18}$

Rukiah, membahas fungsi manusia dalam ekonomi Islam yaitu manusia yang menjalankan aktivitas ekonomi sesuai dengan ciri-ciri dan karakteristik yang Allah kehendaki di dalam Islam, serta strategi jangka panjang yang berkaitan dengan SDM Syariah menghadapi MEA melalui pemerintah mendukung berdirinya lembaga pendidikan dan konsentrasi terhadap lembaga

http://journal.febi.iainimambonjol.ac.id/index.php/almasraf/article/downloadSuppFile/.../79, diakses 26 April 2016.

${ }^{12}$ Tri Wikaningrum, Praktek dan Kebijakan..., diakses 15 Desember 2016.

${ }^{13}$ Rozalinda, Konsep Manajemen Sumber Daya Manusia..., diakses 20 November 2016.

${ }^{14}$ Fahadil Amin Al Hasan dan Muhammad IrfanMaulana, Meningkatkan Kualitas..., diakses 27 Februari 2017.

${ }^{15}$ Asnaini, Pengembangan Mutu SDI..., diakses 27 Februari 2015.

${ }^{16}$ Rita Monica, Pengaruh Pelatihan Terhadap Peningkatan Kinerja Pegawai Pada PT Bank Negara Indonesia Tbk Cabang Bukittinggi, Fakultas Ekonomi, STIE Haji Agus SalimBukittinggi, 2008

${ }^{17}$ Puri Hariyadi Nugroho, Korelasi Pelatihan dan Pengembangan Dengan Kualitas Kerja SDI Bank Syariah, Fakultas Syariah dan Hukum, UIN Syarif HidayatullahJakarta, 2010.

${ }^{18}$ Ahmad Aulia, Pengaruh Pelatihan dan Pengembangan Manajemen Sumber Daya Insani Terhadap Peningkatan Etos Kerja Pegawai Bank Syariah Bukopin Cabang melawai (Konsentrasi Perbankan Syariah, Prodi Muamalat, Fakultas Syariah dan Hukum, UIN Syarif HidayatullahJakarta, 2011. 
keuangan syariah, mengoptimalkan munculnya peraturan-peraturan, regulasi mengenai SDM dan sosialisasi Ekonomi dan Perbankan Syariah kepada masyarakat. ${ }^{19}$

Berdasarkan hasil penelitian sebelumnya, ada perbedaan antara hasil penelitian terdahulu dengan penelitian yang akan peneliti lakukan. Peneliti menganggap perlu mengadakan penelitian lebih lanjut dan spesifik tentang strategi manajemen sumber daya insani pada salah satu lembaga perbankan yang akan merubah statusnya dari basis konvensional menjadi basis syariah, dan penelitian ini belum ditemui subyek dan obyek yang serupa dari penelitian-penelitian sebelumnya. Oleh sebab itu, peneliti menitik beratkan pada strategi manajemen sumber daya insani dalam konversi BPR menjadi BPR Syariah Mustaqim Sukamakmur provinsi Aceh.

Seiring dengan perkembangan bank di Indonesia, telah banyak bermunculan bank konvensional yang mengubah kegiatan usahanya menjadi bank syariah. Pendirian bank syariah ini tentunya berdasarkan prinsip syariah. Berdasarkan Pasal 1 ayat (7) UndangUndang Nomor 21 Tahun 2008 Tentang Perbankan Syariah mengartikan bank syariah sebagai bank yang melaksanakan kegiatan usahanya bedasarkan prinsip syariah dan menurut jenisnya terdiri dari bank umum syariah dan bank perkreditan rakyat syariah. ${ }^{20}$ Alternatif yang dapat dipakai dalam pendirian bank syariah adalah dengan mengkonversi usahanya menjadi sistem syariah sehingga menghasilkan bank syariah.

Perkembangan yang ditunjukkan dengan banyak berdirinya bank syariah, khususnya dalam hal ini melalui konversi yaitu perubahan sistem bank yang semula konvensional dirubah menjadi sistem syariah tersebut tentunya memerlukan strategi yang jitu dalam menarik perhatian masyarakat agar mau menggunakan jasa perbankan syariah. Salah satu pengelolaan paling penting dalam tahapan konversi di samping pemasaran bank adalah pengelolaan terhadap Sumber Daya insani (SDI) yang kompeten, yaitu memiliki kapabalitas ekonomi dan juga kapabalitas tentang syariahnya. Hal ini disebabkan SDI merupakan tulang punggung dalam menjalankan roda kegiatan operasional suatu bank. Untuk itu, penyediaan SDI sebagai motor penggerak operasional bank haruslah disiapkan sedini mungkin. ${ }^{21}$

Pengelolaan tersebut dapat diterapkan melalui Manajemen Sumber Daya Insani (MSDI) yang didefinisikan sebagai suatu proses serta upaya untuk merekrut, mengembangkan, memotivasi, serta mengevaluasi keseluruhan sumber daya manusia yang diperlukan perusahaan dalam pencapaian tujuannya. Pengertian ini mencakup kegiatan yang bermula dari mulai memilih siapa saja yang memiliki kualifikasi serta pantas untuk menempati posisi dalam perusahaan (the man on the right place) seperti yang disyaratkan perusahaan hingga kepada persoalan bagaimana agar kualifikasi ini dapat dipertahankan bahkan ditingkatkan serta dikembangkan dari waktu ke waktu. ${ }^{22}$ Oleh karena MSDI ini merupakan proses yang berkelanjutan, sejalan dengan proses operasi perusahaan, maka perhatian terhadap sumber daya insani ini memiliki tempat yang khusus dalam organisasi perusahaan.

Kontribusi dari SDI tidak hanya dilihat dari kemampuan, pengetahuan, skill, ataupun pengalaman yang mereka bawa saat

${ }^{19}$ Rukiah, Strategi Pengembangan SDI Syariah Menghadapi Pasar Global, jurnal FEBI IAIN Pandangsidipuan Volume 1, No.2 (Juli-Desember 2015), hal. 14-15.

${ }^{20}$ Pasal 1 Ayat (7) UU No. 21 Tahun 2008 Tentang Perbankan Syariah.

${ }^{21}$ Kasmir, Manajemen Perbankan..., hal. 139.

${ }^{22}$ Sadono Sukirno, Pengantar Bisnis, (Jakarta: Kencana, 2006), hal. 173. 
bergabung dengan organisasi, tetapi bagaimana organisasi secara internal mengembangkan dan meningkatkan kemampuan dan skill yang dimiliki oleh setiap SDI untuk mengembangkan kapabilitas karyawan karena suatu pekerjaan akan berpengaruh dengan kapabilitas seseorang, bukan hanya sebagai pemenuhan kewajiban terhadap organisasi. Menurut pandangan SDI, pekerjaan harus dirancang sehingga tugas tidak lagi dianggap sebagai upaya untuk tidak menghargai atau mengurangi makna sebagai manusia, tetapi sebaliknya memperbolehkan para pekerja untuk menggunakan potensi mereka secara penuh. ${ }^{23}$ Peran organisasi dalam hal ini ialah menentukan calon karyawan, posisi karyawan, tugas karyawan, dan pengembangan karyawan guna pencapaian tujuan organisasi. Semua itu terkait dengan penempatan tenaga kerja yang sesuai dengan kualifikasi yangdibutuhkan dalam organisasi. Praktek-praktek MSDI yang dijalankan dengan tepat akan mendukung dan meningkatkan "nilai" yang dimiliki oleh karyawan dalam organisasi.

Dengan penentuan standar SDI yang baik dalam organisasi diharapkan dapat menunjang jalannya efektivitas organisasi karena bekerja dengan orang-orang yang tepat, posisi yang tepat, skilland knowledge yang maksimal, kerjasama yangbaik, sehingga pencapaian tujuan organisasi akan dapat dicapai dengan semua kontribusi dari peran karyawan di dalamnya.

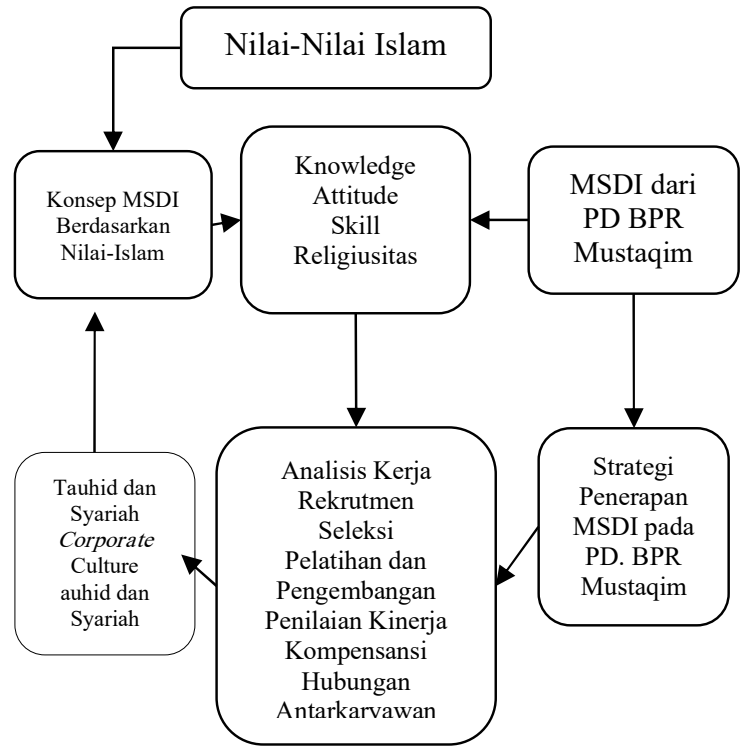

Gambar 2. Kerangka Teori

\section{DATA DAN METODOLOGI}

Penelitian ini menggunakan pendekatan kualitatif dengan menggunakan metode deskriptif untuk menggambarkan fenomenafenomena yang ada, baik fenomena yang bersifat alamiah ataupun rekayasa manusia. ${ }^{24}$ Fenomena yang dideskripsikan dalam penelitian ialah strategi Manajemen Sumber Daya Manusia (MSDI) pada PD BPR Mustaqim Suka Makmur Provinsi Aceh dalam rangka penyiapan proses konversi. Adapun jenis penelitian ialah field research (penelitian lapangan) dan library research (penelitian kepustakaan), di mana keduanya digunakan untuk mengumpulkan data penelitian. Bentuk pertama (field research) diaplikasikan pada saat penghimpunan informasi terkait strategi MSDI pada PD BPR Mustaqim, sedangkan penelitian library research digunakan untuk merumuskan konsep berdasarkan data literatur yang berkaitan dengan MSDI.

Berdasarkan dua jenis penelitian di atas, maka sumber data ini dapat digolongkan

${ }^{23}$ Sanerya Hendrawan, Indraswari, Sylvia yazid, Pengembangan Human Capital, (Yogyakarta: Graha Ilmu, 2012), hal. 148

${ }^{24}$ Hamid Patilima, Metode Penelitian Kualitatif, (Jakarta: Alfabeta, 2011), hal. 3. 
menjadi dua bentuk yaitu primer dan sekunder. Data primer berupa data belum diolah yang diperoleh melalui wawancara dengan Manajer Sumber Daya Manusia dan observasi pada BPR Mustaqim, sedangkan data sekunder berupa hasil studi literatur dan dokumentasi pendukung hasil penelitian. Kedua sumber data tersebut diperoleh dengan menggunakan teknik pengumpulan data berikut ini:

1. Wawancara yakni teknik mengumpulan data dengan mengajukan beberapa pertanyaan kepada informasi terkait strategi MSDI dan ketentuan SDI yang ditetapkan pada PD BPR Mustaqim. Wawancara dilakukan dengan 2 (dua) orang narasumber yaitu manajer sumber daya insani dan ketua tim konversi BPR Mustaqim. Alasan pengambilan 2 (dua) orang narasumber tersebut dikarenakan sesuai dengan permasalahan penelitian dan cukup memadai untuk mendapatkan informasi yang berkaitan. Kemudian peneliti juga melakukan wawancara dengan pihak Bank Muamalat, untuk mendapatkan informasi tambahan dan sebagai data pendukung untuk menguatkan hasil penelitian terhadap strategi MSDM yang seharusnya ada pada perbankan syariah;

2. Observasi ialah pengamatan sebagai lanjutan dari wawancara untuk menambah informasi penelitian yang berkaitan dengan strategi MSDI pada PD BPR Mustaqim;

3. Studi kepustakaan ialah teknik pengumpulan data dengan cara mengumpulkan berbagai referensi berupa buku, artikel, jurnal dan publikasi lain yang dapat digunakan sebagai sumber perumusan MSDI;

4. Dokumentasi ialah teknik pengumpulan data berupa arsip-arsip yang dibutuhkan untuk mendukung hasil penelitian baik itu dalam bentuk brosur PD BPR Mustaqim, arsip terkait konversi perbankan dan pendukung lainnya.

Proses akhir penelitian ialah analisis isi, deskriptif dan komparasi. Deskriptif merupakan teknik penguraian hasil penelitian secara menyeluruh untuk mengambarkan mendalam menganai konsep MSDI dan strategi penerapannya pada PD BPR Mustaqim. Setelah diuraikan secara menyeluruh, kemudian hasil penelitian akan dibandingkan dengan nilai-nilai Islam yang terdapat dalam Al-Quran dan Hadis. Adapun sistematika dalam menguraikan hasil penelitian ini ialah sebagai berikut:

1. Reduksi Data (Data Reduction) Reduksi data adalah proses memilih, memusatkan perhatian pada penyederhanaan, pengabstrakan dan mengubah data kasar yang di dapat dari catatan-catatan tertulis yang ada di lapangan.

2. Penyajian Data (Data Display)

Penyajian data adalah kegiatan ketika terdapat berbagai macam informasi yang bisa disusun, sehingga memberi kemungkinan dapat menarik kesimpulan dan mengambil tindakan. Bentuk penyajian data kualitatif yaitu teks naratif (berbentuk catatan lapangan).

3. Penarikan kesimpulan dan verifikasi (conclusion Drawing/verification).

Penarikan kesimpulan dilakukan peneliti secara terus-menerus selama berada di lapangan. Di mulai dari tahap awal pengumpulan data, peneliti mulai mencari arti benda-benda, mencatat keteraturan pola-pola (dalam catatan teori), penjelasan-penjelasan, konfi- 
gurasi-konfigurasi yang mungkin, alur sebab akibat, dan proposisi. ${ }^{25}$

\section{HASIL DAN PEMBAHASAN}

Ekonomi Islam mempunyai karakteristik yang berbeda dengan sistem ekonomi lainnya. Secara umum dapat dikatakan bahwa nilai-nilai Islam terangkum dalam empat prinsip pokok sebagai aksioma dasar ekonomi Islam, yatu: (1) tauhid, (2) keseimbangan, (3) kehendak bebas, dan (4) tanggung jawab. Keempat prinsip tersebut di atas, harus mewarnai aktivitas setiap Muslim termasuk aktivitas ekonominya. Demikian juga dalam pemikiran dan ilmu ekonominya. Haider Naqvi menjelaskan bahwa etika Islam sebagai aksioma dasar ekonomi Islam yang membuat manusia mampu menegakkan tiga hubungan secara simultan dengan Tuhan, diri sendiri dan masyarakat, serta alam. Keempat aksioma tersebut adalah: (1) kesatuan (tauhid); (2) keseimbangan/kesejajaran (al-'adl wa alihsan/equilibrium); (3) kehendak bebas (ikhtiar/free will); (4) rasa tanggung jawab (responsibility). Di atas landasan nilai-nilai inilah manusia mengaktualisasikan dirinya dalam berbagai kegiatan ekonomi. Sudah tentu dengan berpijak pada nilai-nilai ini manusia tidak akan melakukan pilihan pada tindakan mafsadat melalui perbuatan curang, kerusakan, penipuan, suap maupun korupsi karena mereka menyadari apapun yang dilakukannya senantiasa diawasi oleh Allah Yang Maha Mengetahui dan semua yang dilakukannya pasti berimplikasi bagi diri mereka di akhirat kelak. ${ }^{26}$

Karena itu, landasan yang paling mendasar sebagai Sumber Daya Insani (SDI) ialah iman kepada Allah, yang sadar bahwa setiap kegiatan dan tindakannya dalam bekerja selalu diawasi oleh Allah dan tujuan utamanya hanya untuk Allah. Ketika iman menjadi landasan bagi seseorang dalam bekerja dan berorganisasi, maka keimanan menghadirkan beberapa hal, di antaranya adalah:

1. Cenderung memilih yang halal, bukan yang haram.

2. Cenderung menjauhi yang syubhat.

3. Cenderung pada nilai-nilai kebaikan.

4. Menghormati anak buah dan pimpinan.

5. Beretos kerja tinggi dan memperhatikan nilai-nilai kebaikan.

6. Memperhatikan etika dan norma dalam mengelola organisasi/perusahaan.

Selain iman, SDI syariah hendaknya memiliki akhlak dan moral Islami seperti karakter Nabi Muhammad. Beliau memiliki karakter amanah, fathanah, tabligh dan shiddiq. Amanah adalah sikap bisa dipercaya dalam mengemban tanggung jawab yang diberikan kepadanya. Fathanah adalah sikap profesional dalam melakukan berbagai pekerjaan. Tabligh adalah sikap transparan dan bertanggung jawab terhadap setiap hal yang merupakan amanah yang diberikan kepadanya. Shiddiq atau jujur yang berarti setiap SDI syariah harus terpercaya sehingga bisa diandalkan dalam melakukan pekerjaannya. $^{27}$

Selain akhlak dan moral, yang harus dimiliki seorang SDI syariah yaitu kompetensi. Kompetensi adalah serangkaian pengetahuan, kemampuan dan ketrampilan yang dimiliki seseorang, baik itu melekat pada diri manusia ataupun pemberian dari luar. Menurut Abu Fahmi kompetensi yang harus dimiliki SDM syariah, adalah sebagai berikut: ${ }^{28}$

\footnotetext{
${ }^{25}$ Ibid, hal. 246-252.

${ }^{26}$ Haider Naqvi, Menggagas Ilmu Ekonomi Islam (Yogyakarta: Pustaka Pelajar, 2003), hal. 37.

${ }^{27}$ Abu Fahmi, HRD Syariah..., hal. 84.

${ }^{28}$ Ibid, hal. 129.
} 
1. Kompetensi inti, perbankan syariah membutuhkan SDI yang memiliki pandangan dan keyakinan yang sesuai dengan visi dan misi perbankan syariah.

2. Kompetensi perilaku, kemampuan SDI untuk bertindak efektif, memiliki semangat islami, fleksibel dan memiliki jiwa ingin tahu yang tinggi.

3. Kompetensi perilaku, kemampuan SDI untuk bertindak efektif, memiliki semangat islami, fleksibel dan memiliki jiwa ingin tahu yang tinggi.

4. Kompetensi fungsional, kompetensi ini berbicara tentang background dan keahlian. SDI yang dibutuhkan adalah SDI memiliki dasar ekonomi syariah, operasi perbankan, administrasi keuangan dan analisa keuangan.

5. Kompetensi manajerial, SDI yang mampu menjadi team leader, cepat menangkap perubahan dan mampu membangun hubungan dengan yang lain.

Demikian sebuah organisasi ataupun institusi perbankan syariah dapat memasukkan nilai-nilai syariah kedalam perilaku organisasinya. Sehingga sumberdaya insani yang dimiliki akan memberikan konstribusi yang baik terhadap kinerja perbankan syariah kedepan.

\section{a. Peran dan fungsi BPR Mustaqim Sukamakmur}

Pada kasus BPR Mustaqim milik Pemerintah Aceh. Saat ini konsisten menunjukkan komitmennya dalam membantu UMKM dan mendorong perekonomian masyarakat Aceh. Sebagai Badan Usaha milik Pemerintah Aceh, BPR Mustaqim selalu berkontribusi setiap tahunnya menyetor deviden ke kas daerah sebagai Pendapatan Asli Daerah (PAD). Fokus core bisnis Bank adalah penyaluran kredit modal kerja kepada Pemilik Usaha Mikro Kecil dan Menengah (UMKM). BPR Mustaqim juga telah melakukan terobosan yang pro ekonomi kerakyatan, salah satunya dengan membuka kantor di pulau terpencil dan satu-satunya Bank Perkreditan Rakyat yang berkontribusi aktif di wilayah pantai barat-selatan dengan sistem transaksi online system keseluruh unit kerja yang ada di Aceh.

Fokus Utama PD. BPR Mustaqim Sukamakmur pada tahun 2017 adalah melakukan percepatan proses perubahan kegiatan usaha dari sistem Konvensional menjadi sistem Syariah (Konversi) sekaligus melakukan perubahan bentuk badan hukum dan nama Bank sesuai Qanun No.5 Tahun 2015 tentang "Perubahan Bentuk Badan Hukum Perusahaan Daerah Bank Perkreditan Rakyat Mustaqim Sukamakmur menjadi Perseroan Terbatas Bank Pembiayaan Rakyat Syariah Mustaqim Aceh." BPR Mustaqim milik Pemerintah Aceh saat ini konsisten menunjukkan komitmennya dalam membantu UMKM dan mendorong perekonomian masyarakat Aceh. Sebagai Badan Usaha milik Pemerintah Aceh, BPR Mustaqim selalu berkontribusi setiap tahunnya menyetor deviden ke kas daerah sebagai Pendapatan Asli Daerah (PAD). Fokus core bisnis Bank adalah penyaluran kredit modal kerja kepada Pemilik Usaha Mikro Kecil dan Menengah (UMKM). BPR Mustaqim juga telah melakukan terobosan yang pro ekonomi kerakyatan, salah satunya dengan membuka kantor di pulau terpencil dan satu-satunya Bank Perkreditan Rakyat yang berkontribusi aktif di wilayah pantai barat-selatan dengan sistem transaksi online sistem keseluruh unit kerja yang ada di Aceh.

BPR Mustaqim telah mempersiapkan peralihan (konversi) sistem operasionalnya ke sistem syariah sejak awal tahun 2016. Saat ini, kesiapannya untuk konversi telah mencapai $90 \%$ baik dari segi persyaratan dan perubahan anggaran dasar. Hanya saja, berkas tersebut belum disahkan oleh pihak Otoritas Jasa 
Keuangan (OJK), disebabkan pihak bank harus berada di lokasi Banda Aceh, sesuai dengan tuntunan Qanun No. 5 Tahun 2015 yang menyatakan bahwa tempat kedudukan BPR Mustaqim setelah di konversi menjadi BPRS Mustaqim harus berlokasi di Banda Aceh. ${ }^{29}$ Selain itu, pihak bank juga diwajibkan berubah status menjadi Perseroan Terbatas (PT) yang sebelumnya Perusahaan Daerah. Kedua persyaratan inilah yang sedang dilengkapi oleh pihak bank dalam rangka konversi.

\section{b. Kualifikasi Sumber daya insani pada PD BPR Mustaqim dalam Proses Konversi}

Persiapan Sumber daya insani (SDI) pada BPR Mustaqim disesuaikan pada kebutuhan konversi dengan kualifikasi yang ditetapkan oleh PD BPR Mustaqim. Sesuai konsep yang telah dirangkum pada bab sebelumnya, peneliti mengklasifikasikan kualifikasi SDI menjadi empat kategori. Sehingga kualifikasi SDI yang ditetapkan oleh pihak bank dalam rangka penyiapan SDI untuk proses menuju konversi dari sistem konvensional ke sistem syariah juga dapat dikelompokkan berdasarkan klasifikasi tersebut, yaitu pengetahuan, sikap/attitude, skill/ketrampilan, dan religiusitas. Masingmasing kualifikasi tersebut dapat diuraikan sebagai berikut:

\section{Pengetahuan (Knowledge)}

Adapun pengetahuan-pengetahuan yang dibutuhkan oleh PD PBR Mustaqim ialah pengetahuan tentang ekonomi secara umum, konsep ekonomi syariah, aplikasi akad dalam perbankan syariah, regulasi bank syariah dan menguasai teknik perhitungan transaksi syariah. Pengetahuan perbankan syariah pada SDI BPR Mustaqim sejauh ini belum mencakup pada seluruh karyawan. Pihak bank mengatakan bahwa SDI yang sudah mampu memahami pengetahuan terkait perbankan syariah yaitu karyawan pada level pimpinan, manajer, kepala cabang dan karyawan yang bekerja di kantor pusat operasional BPR Mustaqim. Sedangkan karyawan ataupun staf yang tersebar pada kantor cabang di tingkat kabupaten masih harus ditingkatkan pemahaman-pemahaman syariahnya. 30 Padahal pengetahuan tentang perbankan syariah merupakan hal yang sangat penting bagi SDI bank syariah, seperti pernyataan Kepala Cabang Muamalat Peunayong, bahwa pengetahuan tentang perbankan syariah harus ada pada SDI bank syariah. ${ }^{31}$

Bila meninjau dari hasil wawancara dengan pihak PD BPR Mustaqim, maka pihak bank mengukur kualitas karyawannya berdasarkan pengalaman kerja. Hal ini dapat dinilai dari kriteria dalam proses interview yakni pengalaman menjadi faktor utama diterima dan ditolaknya calon karyawan, sedangkan background pendidikan diposisikan setelah pengalaman. Padahal, pendidikan sebenarnya juga melahirkan pengalaman berupa pengalaman akademis, maksudnya melalui pendidikan seseorang dapat mengetahui konsep teori secara mendalam dan seharusnya teori inilah yang menjadi bekal pengetahuan yang nantinya diaplikasikan dalam tataran praktisnya. Akan tetapi, PD BPR Mustaqim meletakkan pengalaman sebagai pertimbangan utama, sehingga bisa saja antara pengalaman dengan pendidikan tidak sesuai dalam artian pendidikan yang ditempuh berbeda jauh dengan bidang kerja yang ia geluti. Hal ini tentunya akan menimbulkan permasalahan pada akhirnya, semua kegiatan yang ia

\footnotetext{
${ }^{29}$ Qanun No. 15 Tahun 2015, Pasal 10.

${ }^{30}$ Wawancara dengan Samsul Bahri, ketua tim konversi BPR Mustaqim Sukamakmur, pada tanggal 22 Mei 2017.

${ }^{31}$ Wawancara dengan Amelia, kepala cabang Muamalat Peunayong, pada tanggal 14 April 2017.
} 
jalankan bukan berdasarkan ilmu yang ia miliki tetapi semata-mata pengalaman yang telah ditemuinya.

Kriteria pengetahuan SDI BPR Mustaqim dapat dilihat dalam bentuk skema berikut:

\section{Gambar 3. Ilustrasi kriteria pengetahuan SDI BPR Mustaqim}

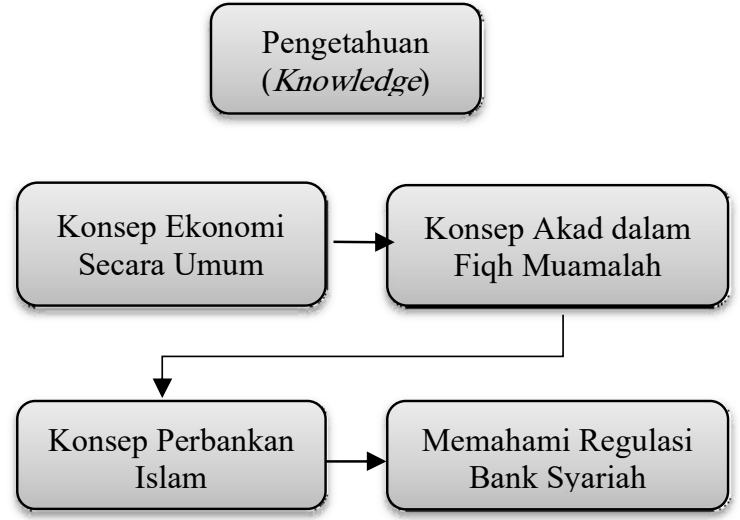

Sumber: Data diolah dari BPR Mustaqim, (2017)

\section{Ketrampilan (skill)}

Keterampilan (skill) merupakan kemampuan untuk menggunakan akal, fikiran, ide dan kreativitas dalam mengerjakan dan mengubah ataupun membuat sesuatu lebih bermakna sehingga menghasilkan sebuah nilai dari hasil pekerjaan tersebut. Skill dapat diartikan sebagai suatu kemampuan untuk menerjemahkan pengetahuan ke dalam praktik sehingga tercapai hasil kerja yang diinginkan. ${ }^{32}$ Adapun untuk keterampilan SDI, pihak bank mengharuskan karyawannya melaksanakan tugas sesuai dengan SOP, mampu menjalankan sistem perusahaan, dan handal dalam memberikan simulasi perhitungan transaksi perbankan syariah. Pihak bank menyatakan bahwa dari segi Informasi Teknologi (IT) tentang syariah sudah ditingkatkan dengan baik, dan pihak BPR Mustaqim yakin bahwa setelah konversi akan lebih memahaminya. ${ }^{33}$
Berkaitan demgan skill SDI pada BPR Mustaqim dapat dibuat skema sebagai berikut:

Gambar 4. Kriteria skill SDI pada BPR Mustaqim

Keterampilan (Skil)

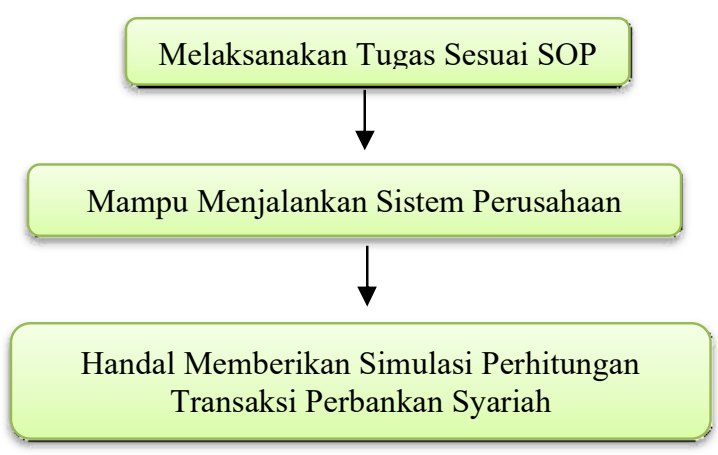

Sumber: Data diolah dari BPR Mustaqim, (2017)

\section{Sikap (Attitude)}

Pada BPR Mustaqim, pihak bank juga menetapkan sikap karyawan dengan kriteria disiplin, bersih, rapi, mengikuti prosedur dan bersikap sopan. Pada attitude, jika dikaitkan dengan cara berpakaian karyawan bank, pihak bank mempunyai standar tersendiri untuk pakaian karyawan. Bagi karyawan laki-laki harus menggunakan celana kain, tidak boleh celana jeans. Sepatu juga harus menggunakan sepatu yang cocok dipakai untuk kantoran. Dan bagi karyawan perempuan, manajer SDI mengatakan bahwa standar yang dilihat adalah pakaian yang rapi, dan menutup aurat. Jadi seragam karyawan memang dibagi oleh pihak bank untuk digunakan pada hari senin, selasa dan rabu. Sedangkan pada hari kamis dan jumat menggunakan pakaian bebas. ${ }^{34}$ Pihak BPR Mustaqim telah memiliki ketentuan bahwa sikap seluruh karyawan harus diperhatikan. Selama proses konversi,

\footnotetext{
${ }^{32}$ Tommy Suprapto, Pengantar ..., hal. 135.

${ }^{33}$ Wawancara dengan Samsul Bahri..., 22 Mei 2017.

${ }^{34}$ Wawancara dengan Samsul Bahri..., 22 Mei 2017.
} 
dalam hal attitude terus dioptimalkan dengan baik.

Berikut dapat dibuat skema terkait attitude SDI pada BPR Mustaqim:

Gambar 5. Kriteria Sikap (Attitude) SDI BPR Mustaqim

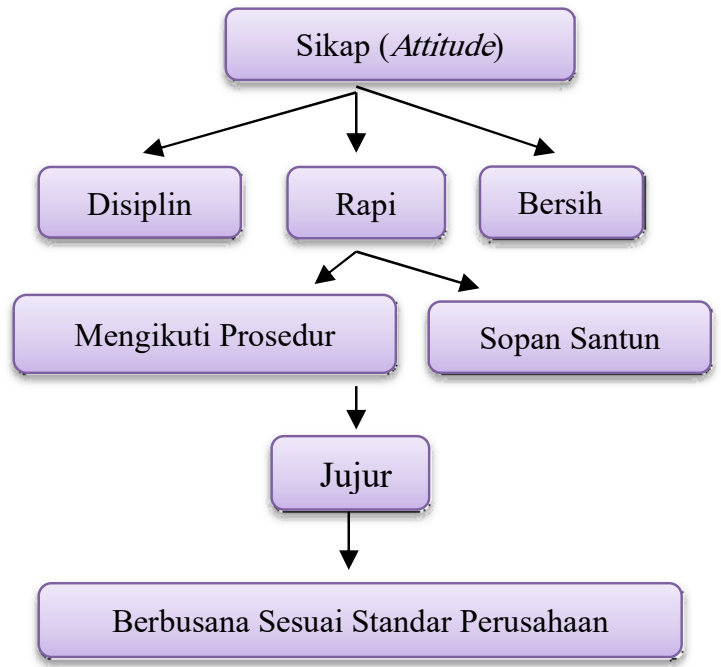

Sumber: Data diolah dari BPR Mustaqim, (2017)

Dari segi attitude, merupakan hal yang sangat penting untuk diperhatikan, khususnya bagi SDI perbankan syariah. Dalam buku Syafi'i Antonio, ${ }^{35}$ dijelaskan bahwa sebuah bank syariah selayaknya memiliki lingkungan kerja yang sejalan dengan syariah. Dalam hal etika, misalnya sifat amanah dan siddiq, harus melandasi setiap karyawan sehingga tercermin integritas eksekutif muslim yang baik.

Selain itu, cara berpakaian dan tingkah laku dari para karyawan merupakan cerminan bahwa mereka bekerja dalam sebuah lembaga keuangan yang membawa nama besar Islam, sehingga tidak ada aurat yang terbuka dan tingkah laku yang kasar. Demikian pula dalam menghadapi nasabah, akhlak harus senantiasa terjaga.

\section{Religiusitas}

Kualifikasi lain yang tidak kalah penting untuk SDI PD BPRS Mustaqim ialah tingkat religiusitas, Menurut Anshori dalam Ghufron \& Risnawati (2010), religiusitas adalah tingkat ketertarikan individu terhadap agamanya. Apabila individu telah menghayati ajaran agamanya, maka ajaran agama akan berpengaruh dalam segala tindakan dan pandangan hidupnya. Aspek religiusitas berkaitan dengan tingkah laku individu dalam menjalankan suatu pekerjaan.

Namun untuk kualifikasi ini, pihak bank belum maksimal meningkatkan pemahaman agama karyawannya. Hal ini dapat dinilai dari kegiatan-kegiatan keagamaan karyawannya, di mana perhatian PD BPR Mustaqim dalam pelaksanaan ibadah belum sepenuhnya tercermin dalam program perusahaan ini, misalnya pihak bank tidak memprioritaskan karyawan menjalan-kan salat tepat waktu dan berjamaah. Selain itu, pihak bank juga belum mempunyai kegiatan amal yang dilaksanakan secara rutin. Sehingga pada realnya, tingkat religiusitas pada karyawan BPR Mustaqim belum maksimal terpenuhi.

Aspek religiusitas yang telah diterapkan pada BPR Mustaqim hanya dalam melakukan rutinitas doa bersama. ${ }^{36}$ Doa bersama merupakan salah satu dimensi dalam religiusitas. Religious/Spiritual Coping, merupakan coping stress atau cara mengatasi stres seorang individu dengan menggunakan pola dan metode seperti dengan berdoa. Seperti hasil wawancara yang peneliti lakukan pada bank muamalat, yang mana pihak bank telah menerapkan peraturan khusus dalam melakukan kegiatan keagamaan, yaitu wajib melakukan shalat lima waktu secara berjamaah. Ibadah shalat juga harus dilakukan tepat waktu. ${ }^{37}$

\footnotetext{
${ }^{35}$ Muhammad Syafi'i Antonio, Bank Syariah Dari Teori dan Praktek(Jakarta: Gema Insani, 2001), 34.

${ }^{36}$ Wawancara dengan Samsul Bahri..., 22 Mei 2017.

${ }^{37}$ Wawancara dengan Amelia..., 14 April 2017.
} 
Berikut dapat ditulis terkait religiusitas pada BPR Mustaqim dalam bentuk skema:

Gambar 6. Kriteria Religiusitas SDI BPR Mustaqim

Religiusitas

Pihak Bank tidak memprioritaskan karyawan untuk menjalankan shalat tepat waktu dan berjamaah

Belum melakukan pengajian mingguan

Belum menyelenggarakan ceramah agama

Kegiatan Keagamaan yang sudah diterapkan yaitu doa bersama

Sumber: Data diolah dari BPR Mustaqim, (2017)

Keempat kategori yang telah diklasifikasikan tersebut menjadi kualifikasi ideal karena didukung oleh pendapat tokoh dan peneliti terdahulu, seperti yang dinyatakan oleh Muhammad ${ }^{38}$. Bahwa lembaga keuangan syariah adalah lembaga yang cukup unik, sebab di dalamnya melibatkan orang-orang yang memiliki kualifikasi dan kompetensi yang bukan hanya ahli dalam bidang ekonomi, keuangan dan perbankan, namun mereka harus memiliki kualifikasi dan kompetensi syariah. Dua sisi kualifikasi dan kompetensi ini dipadukan secara integral. Secara ideal, lembaga keuangan syariah ke depan akan sangat membutuhkan SDI yang ihsan, yaitu SDI yang memiliki keahlian ilmu ekonomi dan pengetahuan syariah.
Didukung oleh pendapat Zainuddin ${ }^{39}$ yang menyatakan bahwa, dalam lembaga keuangan, terdapat perbedaan antara sumber daya insani lembaga keuangan syariah dan konvensional. Lembaga keuangan syariah membutuhkan sumber daya insani yang tidak hanya menguasai persoalan operasional dan manajerial saja, akan tetapi juga mengetahui betul tentang fiqh ekonomi Islam atau fiqh almuamalah yang bersumber pada nilai-nilai keislaman. Kemudian selain masalah profesionalisme, Muhammad menyatakan dalam nilai-nilai ajaran Islam harus berlandaskan pada sifat Nabi SAW yaitu sifat: amanah, siddiq, tabligh, dan fathanah.

Didukung juga oleh Zainuddin yang menyatakan dalam hal etika, sifat shiddiq dan amanah, harus melandasi setiap karyawan sehingga tercermin integritas eksekutif muslim yang baik. Karyawan Lembaga Keuangan Syariah juga harus skillfull dan professional (fathanah) dan mampu melaksanakan tugas secara team work dimana informasi merata di seluruh fungsional organisasi (tabligh). Begitupun dalam hal reward dan punishment, hal tersebut sangat diperlukan sebagai pelaksanaan prinsip keadilan yang sesuai dengan syariah.

Hal yang paling penting sebagai SDI syariah ialah iman kepada Allah yang berimplikasi pada tingkat religiusitas yang tinggi, ${ }^{40}$ dengan adanya iman dan aspek religiusitas ini SDI syariah sadar bahwa setiap kegiatan dan tindakannya dalam bekerja selalu diawasi oleh Allah dan tujuan utamanya hanya untuk Allah.

\section{c. Strategi Manajemen Sumber Daya Insani Sesuai dengan Nilai-Nilai Islam untuk Diterapkan pada Konversi PD BPR Mustaqim}

\footnotetext{
${ }^{38}$ Muhammad, Kualifikasi Sumber..., 2003.

${ }^{39}$ Zainuddin Ali, Hukum Ekonomi Syariah, (Jakarta: Sinar Grafika, 2009), hal. 48.

${ }^{40} \mathrm{Abu}$ Fahmi, dkk, HRD Syariah Teori dan Implementasi, Manajemen Sumber Daya Manusia Berbasis Syariah, (Jakarta: PT Gramedia Pustaka Utama, 2014), hal. 84.
} 
Kaitan antara praktek manajemen sumber daya insani, dengan kualifikasi SDI yang ideal, khususnya pada BPR Mustaqim yang sedang menuju konversi, mempunyai hubungan timbal balik. Praktek manajemen sumber daya insani sangat berkaitan dengan kebijakan yang diambil oleh pihak perusahaan.

Dalam hal ini, pihak BPR Mustaqim menerapkan strategi peningkatan kualitas SDI dengan beberapa praktek. Praktek manajemen sumber daya insani perlu disesuaikan dengan konteks bahwa BPR Mustaqim harus meningkatkan kualitas SDI, baik karyawan yang telah ada sebelumnya maupun karyawan yang baru direkrut, untuk keberhasilan konversi dari sistem konvensional ke sistem syariah.

Analisis strategi manajemen Sumber Daya Insani (SDI) sesuai dengan implementasi manajemen SDI Syariah pada BPR Mustaqim Aceh untuk meningkatkan kualitas karyawan adalah sebagai berikut:

1. Rekrutmen

2. Seleksi

3. Pelatihan dan pengembangan

4. Penilaian kinerja

5. Kompensasi

6. Hubungan antar karyawan

Amir Nuruddin dalam Abu Fahmi ${ }^{41}$ menjelaskan bahwa keberadaan SDI di suatu lembaga memang sangat menentukan kinerja, produktivitas, dan keberhasilan suatu institusi. Bagi perbankan syariah sebagai institusi bisnis yang berbasis nilai dan prinsip syariah, kualifikasi dan kualitas SDI jelas lebih menuntut adanya keterpaduan antara knowledge, skill, dan ability dengan komitmen moral Islami dan integritas pribadi. Oleh karena itu, kualifikasi dan kualitas SDI syariah yang paling utama adalah pemahaman terhadap nilai-nilai tauhid yang menjadi pembeda antara praktiksi ekonomi secara umum dengan ekonomi syariah.

Oleh karena itu, kondisi eksisting karyawan BPR Mustaqim yang akan konversi dari sistem konvensional ke sistem syariah perlu ditingkatkan. BPR Mustaqim memang sudah menerapkan praktek manajemen sumber daya insani tersebut. Namun, praktekpraktek dalam manajemen sumber daya insani yang telah dijalankan oleh pihak BPR Mustaqim masih harus dioptimalkan.

Dari hasil penelitian ini, penulis menganalisis bahwa manajemen SDI berbasis syariah yang diterapkan oleh BPR Mustaqim masih terdapat beberapa kekurangan, yaitu:

1) Pada praktek rekrutmen dan seleksi masih menggunakan teknik dan prosedur yang lama. Pada proses rekrutmen, pihak BPR Mustaqim belum memfokuskan pada kriteria syariah yang harus dimiliki oleh calon karyawan. Kemudian pada proses seleksi, pihak bank belum menerapkan manajemen seleksi syariah untuk menggali calon karyawan yang berkompeten dan berkarakter syariah.

2) Pada praktek pelatihan dan pengembangan, pihak bank hanya memfokuskan pelatihan (training) untuk peningkatan pengetahuan dan keterampilan saja. Namun budaya perusahaan syariah belum diperhatikan sebagai bentuk manifestasi dari nilai tauhid yang berefek pada pola pikir, karakter, dan perilaku Islami karyawan.

3) Pemberian kompensasi, penilaian kinerja, dan manajemen hubungan antarkaryawan masih harus dioptimalkan.

Berikut ilustrasi strategi manajemen sumber daya insani pada proses konversi BPR Mustaqim Aceh:

\footnotetext{
${ }^{41}$ Abu Fahmi, dkk, HRD Syariah..., hal. 124.
} 
Gambar 7. Strategi Manajemen SDI BPR

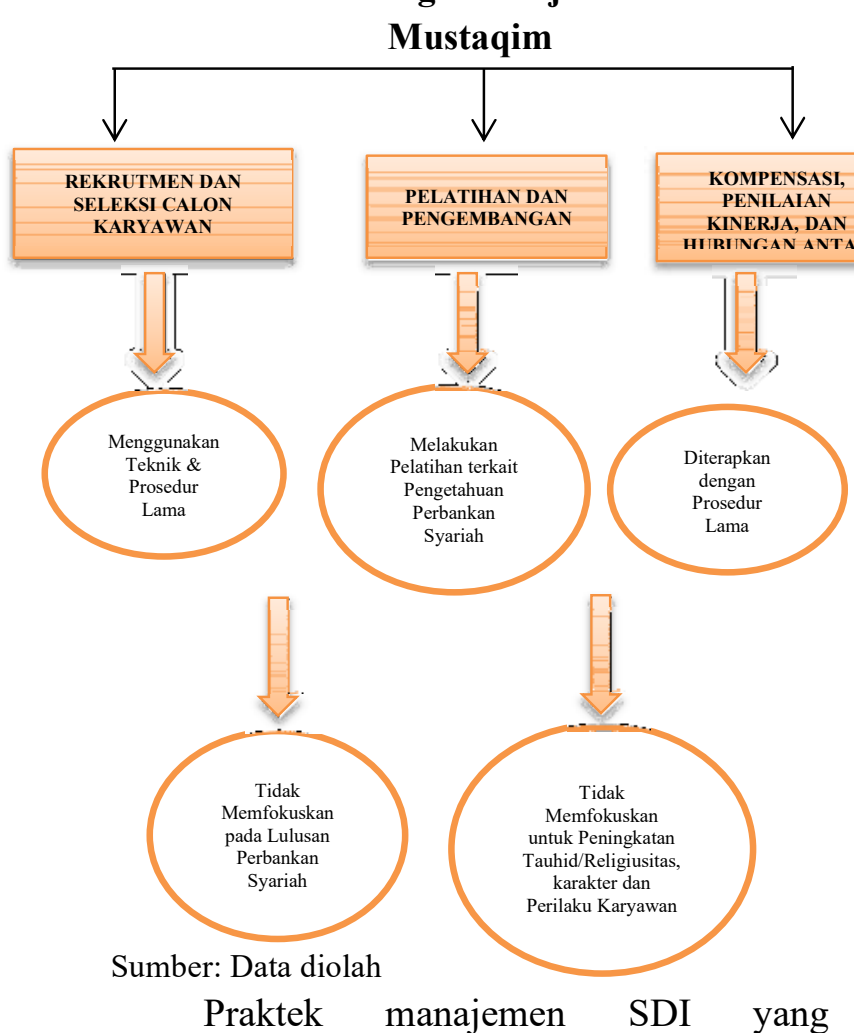

diterapkan dalam operasionalisasi oleh pihak BPR Mustaqim dapat dikembangkan dengan mengimplementasikan manajemen SDI syariah. Bila digambarkan dengan skema, maka dapat diuraikan sebagai berikut:

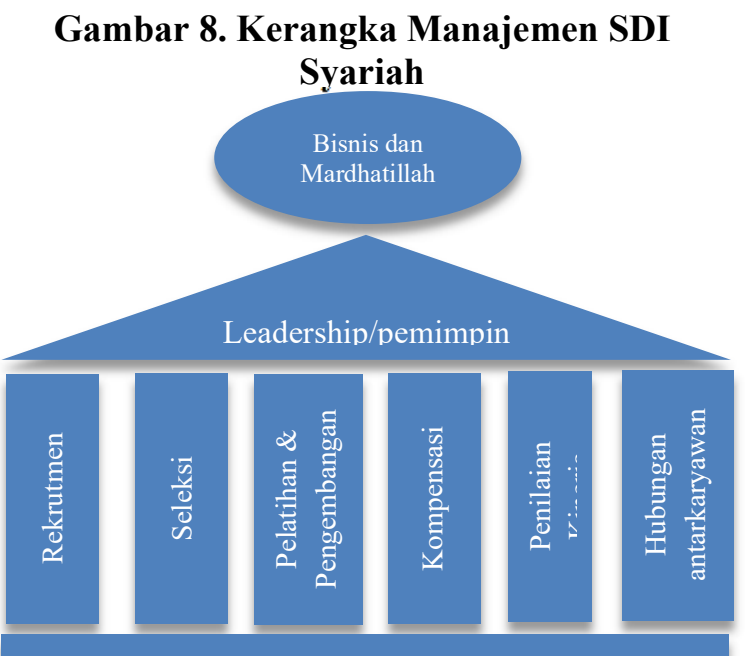

Budaya Perusahaan Syariah (Syariah Corporate Culture)

Tauhid (Religious Spirituallity)

Sumber: Data diolah
Dari skema tersebut dapat dilihat bahwa Religious Spirituality (Tauhid) merupakan fondasi utama bangunan manajemen SDI yariah. Fondasi selanjutnya adalah syariah orporate culture yang merupakan manifestasi dari tauhid. Kemudian dindingdinding bangunan tersebut adalah fungsifungsi manajemen SDI yang dioperasikan dalam perusahaan untuk mendukung tujuan perusahaan. Atap bangunan adalah leadership yang berfungsi mengharmonisasi seluruh aspek-aspek dalam bangunan yang tujuan akhirnya adalah meningkatkan bisnis yang diridhai Allah swt.

Tauhid merupakan fondasi utama dalam manajemen SDI syariah, karena dapat menjadi landasan bagi penumbuhkembangan karakter insan muslim dalam segala sendi kehidupan, tidak terkecuali ketika berkaitan dengan manajemen sumber daya manusia yang subjek dan objeknya juga manusia.

Upaya meningkatkan kualitas SDI pada perbankan syariah sangat berhubungan dengan budaya perusahaan (corporate culture) yang dimiliki oleh perusahaan. Pada lembaga perbankan syariah budaya perusahaan menjadi fondasi yang sangat penting, yaitu mengimplementasikan syariah corporate culture (budaya perusahaan syariah). Oleh karena itu, pada BPR Mustaqim yang akan melakukan konversi ke syariah dapat menerapkan praktek budaya perusahaan syariah sebagai bentuk kepercayaan dan nilai-nilai Islami yang mewarnai seluruh pola, perilaku, sikap, dan aturan-aturan dalam suatu perusahaan.

Selanjutnya Hafidhuddin dalam Abu Fahmi 42 menyatakan bahwa budaya perusahaan syariah juga harus mencerminkan nilai-nilai Islam, misalnya; cara melayani nasabah, cara berpakaian, membiasakan

${ }^{42}$ Ibid, hal. 151. 
shalat berjamaah, berdoa sebelum dan setelah selesai bekerja.

Berikut praktek perusahaan syariah ${ }^{43}$ yang dapat diterapkan dalam mewujudkan nilai-nilai Islam pada perbankan syariah, khususnya BPR Mustaqim Aceh yang akan konversi:

1. Kepribadian Karyawan dalam Hubungan dengan Allah Swt.

2. Kepribadian Karyawan dalam Hubungan dengan Sesama Manusia

3. Berdoa Sebelum dan Sesudah Kerja

4. Berdoa Sebelum dan Sesudah Rapat

5. Budaya Salam

6. Sikap Ramah dan Melayani

7. Berbusana Islami

8. Lingkungan Kerja yang Bersih, Sehat, dan Islami

9. Ceramah Diniyah Rutin atau Berkala

Gambaran mengenai sifat-sifat tersebut seharusnya dimiliki dalam diri praktisi ekonomi syariah. Manifestasi nilai tauhid tersebut dapat dipraktekkan untuk meningkatkan religiusitas karyawan yang ada pada BPR Mustaqim Aceh dengan berupaya membentuk budaya perusahaan yang Islami dan melaksanakan kegiatan-kegiatan keagamaan.

Implementasi budaya perusahaan syariah memang tidak mudah. Hal ini harus dapat dicerminkan oleh pimpinan bank syariah. Pada BPR Mustaqim, persiapan konversi harus diupayakan seoptimal mungkin. Manajemen SDI yang berbasis syariah sangat menentukan keberhasilan konversi yaitu dengan menerapkan prosedurprosedur, teknik, dan mekanisme yang terangkum dalam nilai-nilai tauhid. Manajemen SDI tersebut harus memperhatikan peningkatan kualifikasi untuk existing karyawan maupun karyawan baru. Standar kualifikasi yang paling penting yaitu pada tingkat pengetahuan dan keterampilan terkait perbankan syariah, tingkat attitude dan moralitas, serta tingkat religiusitas yang dimiliki oleh karyawan.

\section{E. KESIMPULAN}

Berdasarkan hasil penelitian dan pembahasan di atas maka peneliti dapat menyimpulkan hal-hal sebagai berikut:

1. Kualifikasi ideal Sumber Daya Insani (SDI) pada BPR Mustaqim yaitu memiliki keimanan dan religiusitas, attitude berupa akhlak dan moral yang Islami (terangkum dalam nilai-nilai siddiq, amanah, tabligh, dan fathanah) dan kompetensi (pengetahuan syariah dan keterampilan). Kualifikasi tersebut harus dipenuhi agar didapatkan SDI yang ihsan, yaitu SDI yang memiliki kapabilitas, baik dalam ilmu ekonomi maupun syariah. SDI BPR Mustaqim Aceh secara keseluruhan belum sepenuhnya ideal, yaitu dari segi pengetahuan tentang perbankan Islam dan tingkat religiusitas berupa amalan-amalan dari manifestasi nilai tauhid.

2. Strategi manajemen sumber daya insani dalam meningkatkan kualitas SDI diterapkan dalam beberapa praktek, yaitu praktek rekrutmen, seleksi, pelatihan dan pengembangan, kompensasi, penilaian kinerja, dan hubungan antar karyawan. Namun praktek manajemen sumber daya insani yang diterapkan oleh BPR Mustaqim belum sepenuhnya optimal. Masing-masing praktek tersebut, pihak BPR Mustaqim perlu mendesain dan mengembangkan metode, teknik dan prosedur yang baik dengan menerapkan manajemen SDI syariah dan memperhatikan nilai-nilai tauhid yang diimplementasikan ke dalam budaya perusahaan syariah, agar kualitas SDI pada

\footnotetext{
${ }^{43}$ Ibid., hal. 153.
} 
BPR Mustaqim dapat meningkat sesuai dengan tujuan bank yaitu keberhasilan konversi ke syariah.

\section{Saran}

Saran-saran yang dapat diberikan sebagai tindak lanjut dari hasil penelitian adalah sebagai berikut:

1. BPR Mustaqim Aceh, diharapkan pada waktu yang akan datang terus memberi perhatian lebih terhadap manajemen sumber daya manusia baik dalam praktek rekrutmen, seleksi, pelatihan dan pengembangan, penilaian kinerja, kompensasi, dan hubungan antar karyawan. Praktek manajemen sumber daya tersebut tentunya tidak terlepas dari nilai-nilai Islami agar dapat terus meningkatkan kualitas SDI yang berkompeten baik dari segi pengetahuan, skill/keterampilan, attitude/sikap dan moral, serta keimanan dan tingkat religiusitasnya.

2. Bagi pemerintah sebagai penanggung jawab pendidikan, penyelenggara pendidikan, (perguruan tinggi), dan pengguna (bank) perlu melakukan kerjasama dalam rangka meningkatkan sumber daya manusia di lembaga keuangan syariah, baik pada Bank Umum Syariah (BUS), Unit Usaha Syariah (UUS), maupun Bank Pembiayaan Rakyat Syariah (BPRS).

3. Bagi penelitian selanjutnya, perlu mempertimbangkan persepsi karyawan terhadap strategi manajemen sumber daya manusia yang diterapkan pada BPR Mustaqim Aceh, sehingga peningkatan SDI dapat dipertimbangkan sesuai kebutuhan karyawan.

\section{DAFTAR PUSTAKA}

Abu Fahmi, dkk, HRD Syariah Teori dan Implementasi, Manajemen Sumber Daya Manusia Berbasis Syariah, Jakarta: PT Gramedia Pustaka Utama, 2014.

Ahmad Aulia, Pengaruh Pelatihan dan Pengembangan Manajemen Sumber Daya Insani Terhadap Peningkatan Etos Kerja Pegawai Bank Syariah Bukopin Cabang melawai (Konsentrasi Perbankan Syariah, Prodi Muamalat, Fakultas Syariah dan Hukum, UIN Syarif Hidayatullah Jakarta, 2011.

Asnaini, Pengembangan Mutu SDM Perbankan Syari'ah: Sebagai Upaya Pengembangan Ekonomi Islam, La Riba, Jurnal Ekonomi Islam Vol.II, No.1, Juli 2008, diakses 27 Februari 2015 .

Departemen Agama Republik Indonesia. AlQuran dan terjemahannya.

Fahadil Amin Al Hasan dan Muhammad Irfan Maulana, Meningkatkan Kualitas Sumber Daya Insani Di Lembaga Kuangan Syariah Dalam Menghadapi Persaingan Global, SOSIO DIDAKTIKA: Social Science Education Journal, 3 (1), Juni 2016, 27 36, diakses 27 Februari 2017.

Haider Naqvi, Menggagas Ilmu Ekonomi Islam, Yogyakarta: Pustaka Pelajar, 2003.

Hamid Patilima, Metode Penelitian Kualitatif, Jakarta: Alfabeta, 2011.

Kasmir, Manajemen Perbankan, Jakarta: Rajawali, 2008.

Muhammad Mustaqim, Prinsip Syariah dalam Manajemen Sumber Daya Manusia (Studi Implementasi Manajemen Sumber Daya Manusia UMKM di Kudus), Jurnal Penelitian Vol. 10, No. 2, Agustus 2016, 
Muhammad Syafi'i Antonio, Bank Syariah Dari Teori dan Praktek, Jakarta: Gema Insani, 2001

Muhammad, Manajemen Bank Syariah, Yogyakarta: (UPP) AMP YKPN, 2002.

Puri Hariyadi Nugroho, Korelasi Pelatihan dan Pengembangan Dengan Kualitas Kerja SDI Bank Syariah, Fakultas Syariah dan Hukum, UIN Syarif Hidayatullah Jakarta, 2010.

Rita Monica, Pengaruh Pelatihan Terhadap Peningkatan Kinerja Pegawai Pada PT Bank Negara Indonesia Tbk Cabang Bukittinggi, Fakultas Ekonomi, STIE Haji Agus Salim Bukittinggi, 2008

Rozalinda, Konsep Manajemen Sumber Daya Manusia : Implementasi pada Industri Perbankan Syariah, Jurnal Al Masraf (Jurnal Lembaga Keuangan dan
Perbankan)-Volume 1, No.1, JanuariJuni 2016, diakses 20 November 2016.

Rukiah, Strategi Pengembangan SDM Syariah Menghadapi Pasar Global, jurnal FEBI IAIN Pandangsidipuan Volume 1, No. 2 Juli-Desember 2015.

Sadono Sukirno, Pengantar Bisnis, Jakarta: Kencana, 2006.

Sanerya Hendrawan, Indraswari, Sylvia yazid, Pengembangan Human Capital, Yogyakarta: Graha Ilmu, 2012.

Tri Wikaningrum, Praktek dan Kebijakan Manajemen Sumber Daya Manusia pada Perbankan Syariah, Jurnal Siasat Bisnis Vol. 15, No.1 Januari 2011, diakses 15 Desember 2016.

Zainuddin Ali, Hukum Ekonomi Syariah, Jakarta: Sinar Grafika, 2009. 